\title{
The Historicity of The New Bali Lexicon and Formation Projection of Unda-Usuk Bahasa
}

\author{
Putu Sutama ${ }^{1}$, Maria Arina Luardini ${ }^{2 *}$
}

\author{
${ }^{1}$ Universitas Udayana 1 \\ ${ }^{2}$ Universitas Palangka Raya 2 \\ *Corresponding author. Email: maria_luardini@edu.upr.ac.id
}

\begin{abstract}
This research aims to find out the Balinese language evolution in the lexicology field. The Balinese language has grown and improved since the Old Bali, Middle Bali, and New Bali periods. Within the period, the Balinese language absorbed vocabularies from other languages, particularly Javanese, such as Old Javanese (kawi) and Middle Javanese. By using the linguistic framework of historical comparison, it is found that the number of the vocabularies absorbed gained one-third of the dictionary vocabularies - Anggah Ungguling Basa Bali dictionary. It is about 2.500 vocabularies [1]. The absorption period started happening in the XII century when the Bali conquest occurred by the Majapahit troops. While Bali was occupied by the Majapahit people, the Bali social-cultural life was automatically based on the Majapahit kingdom. Since then, a new social system was issued, which is the presence of caste, colour, or dynasty system known as four castes consisting of Brahmana, Ksatria, Waisya, and Sudra. The social stratification affects the system of Balinese language which is the existence of Unda Usuk Bahasa Bali system. The unda usuk Bahasa Bali contains (1) bahasa alus (Singgih, Madya, Sor), and (2) vocabulary (Alus, Mider, Kepara). This language is used by Bali Dataran society (Majapahit people), meanwhile, Bali Aga (native) society do not know the system. The examples of the language are the words 'funeral': aben (andap), aben (alus sor), lebon (alus singgih) or 'father': bapa (andap), bapa (alus sor), aji, agug (alus singgih). The form and meaning similarity in the language aims to provide references about social stratification in the system of culture.
\end{abstract}

Keywords: historicity, lexicon, projection, unda usuk

\section{INTRODUCTION}

The growth and improvement of the Balinese language (BL) are strongly related to the historical process, starting from proto-Austronesian language to ancient, middle, new, and going to modern Balinese language.

On the other hand, the improvement of the Balinese Language is strongly affected by the political and cultural history of a nation [2]), which begins from the military expedition of Majapahit led by Gajah Mada in 1343 AD. The previous traditional social stratification system was based on colour or caste-like in India. However, the system changed into wangsa system (lineage) since the Majapahit empire. From this system, several vocabularies were issued, namely soroh, treh or warih, and kinship group which means genus or species.

Majapahit's power in Bali was started since a regent named Sri Kresna Kepakisan was appointed as a Majapahit deputy king followed by 15 Aryans, 3 Wesias, a Brahmin named Danghyang Nirartha and a hundred of soldiers. From this group, the term Wong
Majapahit was born, meanwhile, native Balinese is known as Wong Bali Aga.

The system of Unda Usuk Bahasa Bali refers to each other between social system (culture) and language system and is constructive. The BL speakers functionally have to know well the presence of social or wangsa system in using Unda-Usuk Bahasa so that the vocabulary choice is not false communicate systematically. The system of Unda Usuk Bahasa Bali as follow:

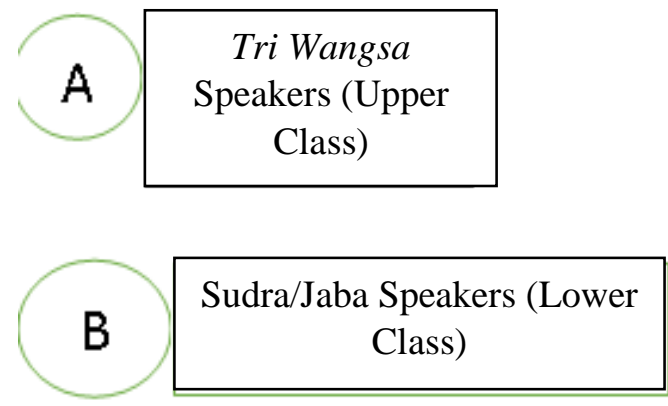

Figure 1. The speaker of Upper Class and Lower Class. 
In general, the speakers of Tri Wangsa communicate with each other by using Bahasa Alus (a language used to respect the interlocutor and someone who talked about it) as the identity of Tri Wangsa. Likewise, the speakers of Sudra/Jaba communicate with each other by using 'general' Bahasa Bali Kepara. These illustrations show the language system horizontally at the same level of speaker stratification. Majapahit people created a traditional social stratification system called as Catur Wangsa system, including:

- Wangsa Brahmana

- Wangsa Ksatria

- Wangsa Waisya

- Wangsa Sudra

Then, the four Wangsa is simplified into two groups keempat, such as: Waisya)

-Class of Tri Wangsa (Brahmana, Ksatria, and

-Class of Sudra

The birth of Wangsa system created the presence of language system called Unda-Usuk bahasa that has many terms in $\mathrm{BL}$ as follow:

-Anggah - Ungguhing Basa

-Masor - Singgih Basa

- Warna- Warna Bahasa

-Anggah - Ungguh Basa

-Polite Form

Vertically, the system of language between Tri Wangsa speakers and Sudra/Jaba speakers or vice versa has many variations. Generally, Tri Wangsa speakers group (upper class) are allowed to use a coarse (general/kepara) language choice (vocabulary) to communicate with Sudra/Jaba class (lower class). The language tradition does not lead to offence or abuse. However, Jaba/Sudra class have to speak respectfully (alus) to Tri Wangsa class (Brahmana, Ksatria, Waisya). If the language used to communicate is wrong in this relation, cultural matters will occur (considered as do not have manners). Hence, Sudra/Jaba class have to ask before about the status or the identity of the people that they have just met or known and that they have not known yet the social-cultural background when they want to communicate with those people. They can begin with the sentence: "Nawegang antuk linggih" (Please tell your status/identity). Surely, the people will answer honestly.

(1) Titiang Ida Bagus / I am Brahmana Ida Bagus

(2) Titiang Gusti / I am Ksatria Gusti

(3) Titiang Dewa / I am Dewa

(4) Titiang Jaba / I am an ordinary person (Sudra)

By knowing the status or identity of the addressee, the communication by using Unda-Usuk bahasa will get along in harmony and respect each other.

\section{METHODOLOGY}

This research is library research by adopting the qualitative descriptive method as the research method. The data collection method used is the observation method which means observing the lexicon forms in books and BL discretionary. The data processing is conducted with the procedure: identification, classification, and categorization. The data analysis applied is comparation method and analysis presentation by using informal and deductive methods.

\section{ANALYSIS}

\subsection{Historicity of Balinese Language Lexicon}

Cultural acculturation caused by the political process cannot be prevented. The strongest impact of sociolinguistic is the presence of cultural acculturation in language. Moreover, there is a language kinship between the two languages. Even though the two languages are not kinship languages, the adaption of language will happen due to the intensity of the speaker interaction naturally. The interaction of the speaker of two languages or more is one of the sources of vocabulary in BL. Javanese people (Majapahit) are Javanese speakers (old and middle/kawi Javanese).

The existence of the social stratification system of Majapahit in Bali automatically creates language acculturation, which is BL with Javanese. It begins from the borrowing process, leads into adoption, and finally is claimed as vocabulary in BL.

Before the social stratification comes in the Balinese language, the social of Catur Wangsa does not know Unda-Usuk Bahasa. The vocabularies in BL dictionary are general: (1) andap, (2) kepara, (3) lumrah or a language for general society / mostly "Destitute People". The numbers of the vocabularies gain 7.000s entries. After the Majapahit stratification social (Catur Wangsa) is constructed, there are new additional vocabularies in the polite form that has a higher meaning called Bahasa Alus. The numbers of these vocabularies gain 2.000s Suwija, [1].

\subsection{Vocabulary of Unda - Usuk Bahasa Bali}

The terminology of Unda Usuk Bahasa is a term referring to Unda Usuk Kosa Kata. Unda Usuk Kosa Kata is a basic concept regarding semantics, that is 'synonym', which has a different form, but the meaning is the same. In Unda - Usuk perception, the meaning is emphasized culturally called the distinction of language "Feeling". Here are the examples of UndaUsuk Kosa Kata regarding several concepts. 
Table 1 . The vocabulary of unda usuk

\begin{tabular}{|c|c|c|}
\hline Concept & $\begin{array}{l}\text { For most people } \\
\text { (Sudra/Jaba) }\end{array}$ & $\begin{array}{l}\text { For Tri Wangsa } \\
\text { class }\end{array}$ \\
\hline Home & Umah & $\begin{array}{l}\text { 1. Gcria } \\
\text { 2. Furi }\end{array}$ \\
\hline Makan & Mididar & $\begin{array}{l}\text { 3. Jero } \\
\text { 1. INgdjeng } \\
\text { 2. INgdrayumidi }\end{array}$ \\
\hline Water & Yeh & $\begin{array}{l}\text { 1. Banyu } \\
\% \text { 'I'oya } \\
3 \text { Tirta }\end{array}$ \\
\hline
\end{tabular}

The table above explains about: 1). The vocabulary of andap/kepara that has only one form is used by 'destitute people', 2). The vocabularies used by Tri Wangsa (upper class) have more than one form based on the social stratification to call.

Semantically, the meaning in andap/kepara and bahasa alus is same as well as the reference. The distinction is only in cultural factor known as "Language Feeling" that means a kind of perception level in the opposition between:

$$
\begin{aligned}
& \text { * Rude - Soft } \\
& \text { * Low - High } \\
& \text { * Bad - Good } \\
& \text { * Impolite - Polite }
\end{aligned}
$$

\subsection{Classification of Unda-Usuk Kosa Kata BB}

Based on the form, the vocabulary in Unda-Usuk $B B$ can be depicted as:

1. Vocabulary that has two forms: (1) andap / kepara / lumrah and (2) bentuk Alus. The andap form is called Andap/Kepara vocabulary, Meanwhile, another one is called Alus Mider vocabulary. These forms are illustrated in the following table:

\section{Table 2. Kosa Kata Andap \& Alus Mider}

\begin{tabular}{|l|l|}
\hline \multicolumn{1}{|c|}{$\begin{array}{l}\text { Vocabulary of Andap / } \\
\text { Kepara }\end{array}$} & \multicolumn{2}{l}{$\begin{array}{l}\text { Vocabulary of Alus } \\
\text { Mider }\end{array}$} \\
\cline { 2 - 2 } - Suba 'sudah' & - sampun \\
- Uli 'dari' & - saking \\
- adu 'lomba' & - centok \\
- adeng 'pelan' & - alon \\
- ajak 'diajak' & - iring \\
\hline
\end{tabular}

In the table above, there are two categories of vocabulary, which are the vocabulary of andap/kepara and Alus Mider. The vocabulary of andap is only used by the speakers of Sudra / Jaba (lower class). While, the vocabulary of Alus Mider is used in greeting the Tri Wangsa speakers (Tri Wangsa Brahmana, Ksatria, and Waisya). The word "Mider" means to everywhere or to all directions. It belongs to the addresser (lower class).
2. Vocabulary that has more than two forms: (1) andap

\begin{tabular}{|c|c|c|c|c|}
\hline \multirow[t]{2}{*}{ Concept } & $\begin{array}{c}\text { Kepara / } \\
\text { andap }\end{array}$ & $\begin{array}{c}\text { A his } \\
\text { Singglh }\end{array}$ & $\begin{array}{l}\text { A his } \\
\text { Sor }\end{array}$ & Kasar \\
\hline & mati & $\begin{array}{l}\text { seda } \\
\text { lcbar }\end{array}$ & padem & bangka \\
\hline Die & madaar & $\begin{array}{l}\text { lina } \\
\text { newata }\end{array}$ & nunas & ngamah \\
\hline Eat & & $\begin{array}{l}\text { Ilgajeing } \\
\text { ngarayunan } \\
\text { ngiyun }\end{array}$ & & \\
\hline Hear & ningeh & mireng & miragi & - \\
\hline
\end{tabular}
/ kepara, (2) Alus Singgih, (3) Alus Sor, and (4) Bahasa Kasar.

Table 3. Vocabulary more than 2 forms

Based on the table above and according to Antropocentric view (human as the centre point), there is vocabulary level in general of the language level of Unda Usuk BB.

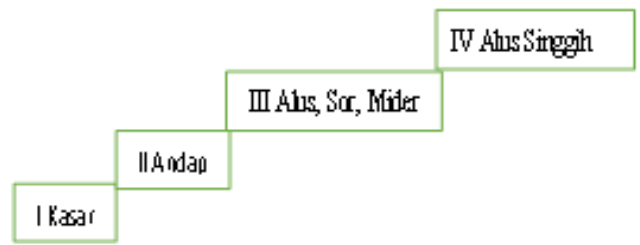

Figure 2. Vocabulary Level in General

\subsection{Formation Projection of Unda Usuk BB}

In the linguistic field, there is a form known as 'meaning changing' which is in this context interpreted as 'feeling' (cultural meaning). The projection in this research is meaning changing from the vocabulary of andap / kepara as basic vocabulary (primary) to the culture of Alus as secondary vocabulary (synonymy), [3]. From a linguistic perspective (Educational Linguistic), there is also a projection term known as "change prediction' Sutama [4].

In this change of Unda Usuk $B B$, meaning changing of culture is understandable from projection perspective to facilitate the understanding of cultural meaning changing from the vocabulary of andap / kepara to the vocabulary of bahasa Alus. By using a projection parameter, the presence of the change can be formulated more simply.

\subsubsection{Linear Projection}

In Unda - Usuk $B B$, some vocabularies have only two forms/meanings: (1) Andap/ Kepara, and (2) Alus Mider. The correlation between these two meanings is called the language of Alus Mider. The formation of Alus Mider language can be formulated as a linear projection since there is only one form of Kepara and 
one form of Alus Mider meaning. This projection can be depicted with a straight curve as follow:

Vocabulary of Andap - Vocabulary of Alus Mider
Example
$\begin{array}{ll}\text { 1. Aksama 'maaf' } & \text { 1. ampura } \\ \text { 2. Aku 'akui' } & \text { 2. angken } \\ \text { 3. Andus 'asap' } & \text { 3. asep } \\ \text { 4. Ane 'yang' } & \text { 4. sane } \\ \text { 5. Aman 'aman' } & \text { 5. trepti }\end{array}$

Figure 3. Linear Projection

\subsubsection{Cross-Border Projection}

On the other hand, in Unda - Usuk BB, some vocabularies have more than two forms/meanings, such as basic vocabulary as general vocabulary called Andap / Kepara vocabulary, and other forms/meanings: (1) kosa kata kasar and (2) kosakata Alus divided into (a) Alus Singgih, (b) Alus Mider and (c) Alus Sor. Based on cross border projection, these formulations show that the formation of Unda - Usuk Bahasa Alus contains the most general basic form/meaning (Andap / Kepara vocabulary) that can have an appropriate synonym in certain cultural contexts. The direction can be to bahasa Kasar or to bahasa Alus. Kosa kata Kasar is usually in the context: fighting, insulting or mocking. Meanwhile, kosa kata Alus might mean: (1) Alus Singgih, (2) Alus Mider and (3) Alus Sor. This projection can be depicted as follow:

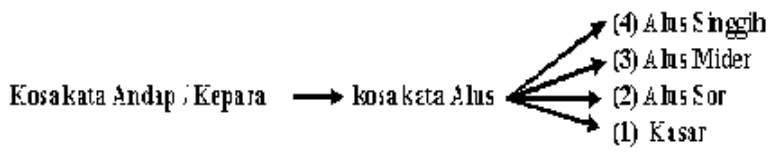

Figure 4. Cross-Border Projection 1

Here is the system of Unda Usuk BB in the context of cross border projection:

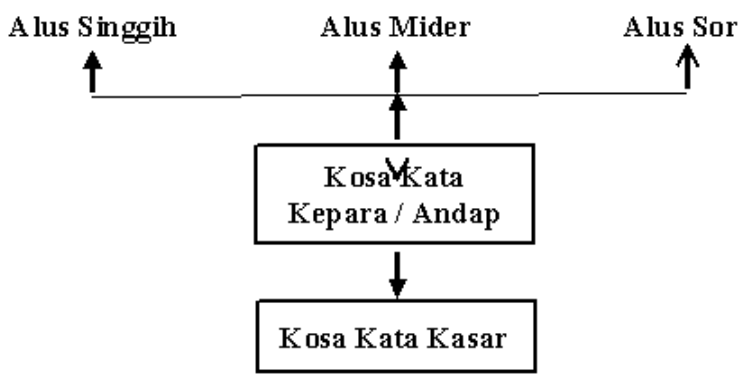

Figure 5. Cross Border Projection 2

The projection formulation in the formation of Unda - Usuk $B B$ is one of the alternative solutions to facilitate in understanding the use, which is being an obstacle so far in BL preservation. However, in this projection, the speakers have to memorize in a categorization way the vocabulary list of Alus Mider, Alus Singgih, and Alus
Sor. This categorization method will compare one to the other.

\section{CONCLUSION}

According to the explanations above, the conclusion can be depicted as follow:

1. The growth and improvement of BL vocabularies are affected by the political history factor in the form of acculturation between Javanese speakers and BL speakers, constructing a new social stratification system called the Catur Wangsa system.

2. The Balinese Language absorbs the elements of Javanese (middle and old Javanese).

3. The position of the absorption language is higher in Semantics Strata called Bahasa Alus (Polite form) in the culture.

4. Based on synonymy perspective, in the system of Unda Usuk BB, some vocabularies have one variety in a basic form/meaning (kosa kata Andap / kepara) which is Alus Mider. Some vocabularies has more than one variety, such as (1) Alus Sanggah, (2) Alus Mider, (3) Alus Sor, and (4) Kosa kata Kasar.

5. According to the projection perspective, the formation of Unda - Usuk BB can be understood in linear projection and cross-border projection.

\section{REFERENCES}

[1] Suwija, I. N. (2008). Kamus Anggah Ungguhing Basa Bali Alus. Denpasar: Palawa Sari.

[2] Chaer, A. (2007). Lekskologi \& Lekskografi Indonesia. Jakarta: PT.Rineka Cipta.

[3] Sutama, P. (2010). Teks Ritual "Pawiwahan" masyarakat adat Bali. Analisis Linguistik Sistemik Fungsional. Denpasar: Universitas Udayana.

[4] Sutama, P. (2011). Kedwibahasaan Penutur dan Tantangan Masa Depan Bahasa Bali. Seminar Nasional Bahasa Ibu. Denpasar: Universitas Udayana. 